\title{
US Fiscal Stimulus and Value of Dollar
}

\author{
Deergha Raj Adhikari \\ University of Louisiana at Lafayette
}

Our study examines the impact of government stimulus spending on the US dollar's exchange rate. We apply the VECM model on US data from 1980 to 2020 with US dollar's exchange rate as the dependent variable and the quantity of domestic money supply, amount of domestic government purchases, quantity of money supplied by the foreign country (China), and the foreign country's output as independent variables. Our study finds that, while the long-run impact of US fiscal stimulus spending on the dollar's exchange rate is negative, it has no effect in the short run. Also, the coefficient associated with the errorcorrection term, ECT, is negative but insignificant at 5\% significance level, which implies that any shortterm fluctuation in the US dollar's exchange rate will not be adjusted toward its long-run value.

Keywords: fiscal stimulus, stationarity, cointegration, VECM, short-run impact, long-run impact, exchange rate, capital inflow, interest rate, etc.

\section{INTRODUCTION}

In last 90 years or so, presidents from both sides of the US political spectrum have used an expansionary fiscal policy through legislations with different names in an attempt to take the U.S. economy out of recession or to stimulate the economy thought to be not growing fast enough.

Although the long term impact of an expansionary fiscal policy is subject to intensive debate, both democratic and republican presidents alike seem to believe that an expansionary fiscal policy stimulates the economy in the short run. In their justification for taking such a policy measure republicans mostly insist that an expansionary fiscal policy mainly focused on cutting business taxes and lowering income tax rates spurs investment, which in turn creates employment, generates income and stimulates the economy. However, democrats offer a very different justification and argument. They insist that an expansionary fiscal policy mainly focused on supporting low-income people and increasing spending on public works projects create demand in the economy raising expected profit for the businesses, thereby raising investment, employment, and income and ultimately stimulating the economy.

The following chart shows the trend of US budget deficit created by an expansionary fiscal policy used during the tenure of all past 3 presidents (republicans and democrat): President Bush (2001-2008), President Obama (2009-2016), and President Trump (2017-2020). 
TABLE 1

US BUDGET DEFICITS (IN TRILLIONS OF DOLLAR)

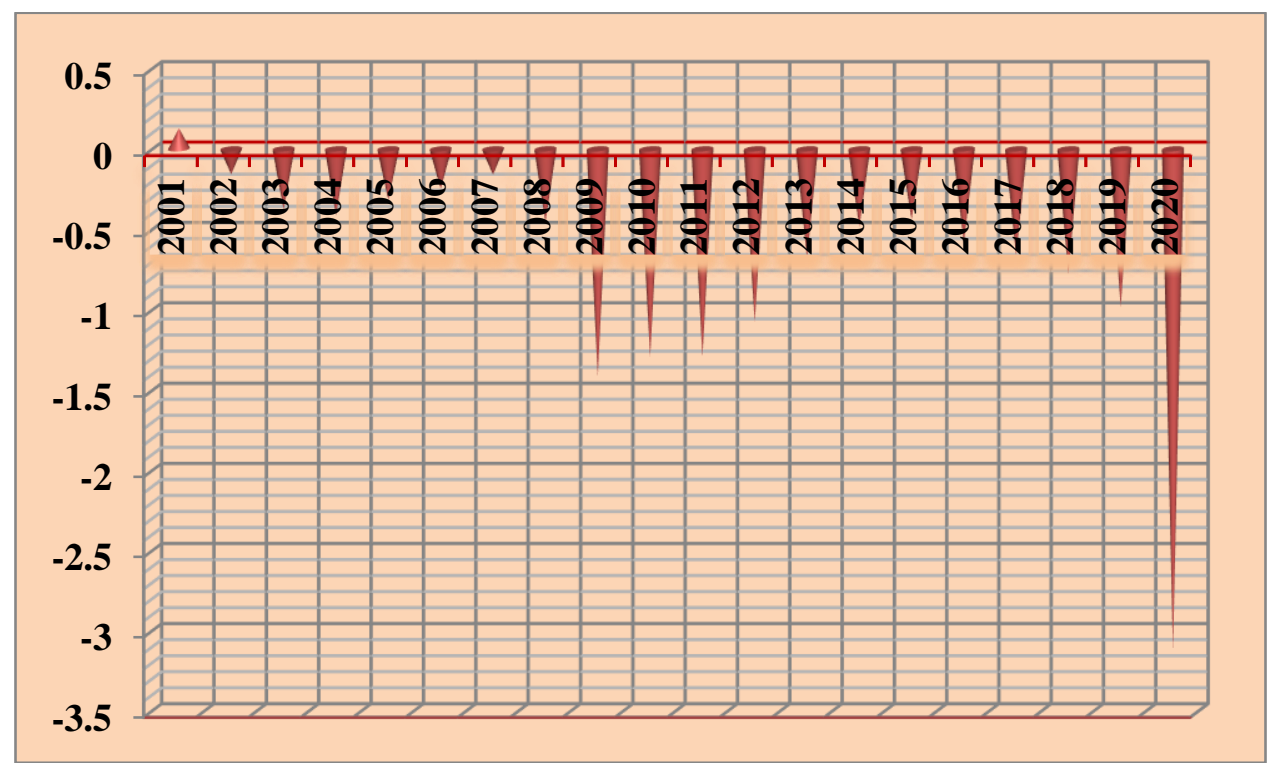

Source: Economic Report of the President, 2021: https://www.govinfo.gov/content/pkg/ERP2021/pdf/ERP-2021.pdf

A macroeconomic policy, such as a fiscal stimulus through deficit government spending, has several repercussions in an open economy, for example, such a policy not only affects a nation's output, employment, and the rate of inflation, it also changes the pattern of income distribution, crowds out domestic investment, affects the exchange rate of domestic currency, and the pattern of international capital flows. In this study, we investigate whether the US stimulus policies (expansionary fiscal policies) have affected the value of or exchange rate of US dollar. Our study examines several previous studies conducted on this issue.

Some of the studies on this issue includes that of Shibamoto, et al. (2014) who explore the comprehensive transmission mechanism of Takahashi's (Japan's then Finance Minister) macroeconomic policy package, including the expectation channel. They construct a structural vector auto-regression (SVAR) model with three state variables (output, price, and the inflation expectations) and three policy variables (fiscal balance, exchange rate, and money stock). Their analysis reveals that the exchange rate adjustment undertaken as an independent policy tool had the strongest effect, and that changes in people's expectations played a significant role for escaping from the Great Depression. As a whole, the choice of the level of the exchange rate was crucial for changing people's expectations as well as promoting exports.

Cova, et al. (2011), in a book analyze the macroeconomic impact of China's 2009-2010 fiscal stimulus package by simulating a dynamic general equilibrium multi-country model of the world economy, showing that the effects on China's economic activity are sizeable: absent fiscal stimulus China's GDP would be 2.6 and 0.6 percentage points lower in 2009 and 2010, respectively. The effects are stronger under a US dollar peg because of the imported loose monetary policy stance from the United States.

Born, et al. (2013) investigate to see if the fiscal multiplier depends on the exchange rate regime? To address this question, they first estimate a panel vector autoregression (VAR) model on time-series data for OECD countries. They then identify the effects of unanticipated government spending shocks in countries with fixed and floating exchange rates, while controlling for anticipated changes in government spending. They find that government spending multipliers are considerably larger under fixed exchange rate.

Ravin, et al. (2012) study the empirical effects of fiscal policy in Denmark since the adoption of a fixed exchange rate policy in 1982. They demonstrate that Denmark's fixed exchange rate implies that the nominal interest rate remains fixed after a fiscal expansion. They also find that, due to the large degree of 
openness of the Danish economy, a sizeable share of the fiscal stimulus was directed towards imported goods.

A study by Ilzetki, et al. (2010) contribute to the debate on the macroeconomic effects of fiscal. Based on a novel quarterly dataset of government expenditure in 44 countries, they find that (i) the output effect of an increase in government consumption is larger in industrial than in developing countries, (ii) the fiscal multiplier is relatively large in economies operating under predetermined exchange rates but is zero in economies operating under flexible exchange rates; (iii) fiscal multipliers in open economies are smaller than in closed economies; (iv) fiscal multipliers in high-debt countries are negative.

Monacelli, et al. (2010) estimate the effects of government spending shocks on the CPI real exchange rate, the trade balance and their co-movements with GDP and private consumption. They decompose the variations of the CPI real exchange rate into variations of the traded goods real exchange rate and the relative price of traded to non-traded goods. They conclude that: (a) a rise in government spending induces a depreciation of the CPI real exchange rate and a trade balance deficit; (b) private consumption rises in response to a government spending shock and therefore co-moves positively with the real exchange rate; and (c) both components of the CPI real exchange depreciate.

McKinnon, et al. (2010), in their study, investigate the case for stabilizing China's exchange rate against the dollar. They find that, before 2005 when the yuan/dollar rate was credibly fixed, it helped anchor China's domestic price level. But gradual RMB appreciation from July 2005 to July 2008 disordered China's financial markets. But after July 2008, the credit crunch induced an unexpected unwinding of the dollar carry trade leading to a sharp appreciation in the dollar's effective exchange rate. This helped People's Bank of China (PBC) better support the fiscal stimulus by promoting a parallel expansion of bank credit.

Castro, Francisco de and Fernandez, L. (2013) analyze the impact of fiscal shocks on the Spanish effective exchange rate over the period 1981-2008 using a standard structural VAR framework. They find that government spending brings about positive responses of output and private consumption, jointly with real appreciation and a fall in trade balances.

Benetrix, Agustin S. and Lane, P. R. (2013) estimate the real exchange rate impact of shocks to government spending for a panel of member countries of the euro area. Their key finding is that the impact differs across different types of government spending, with shocks to public investment generating larger and more persistent real appreciation than shocks to government consumption. They also find different exchange rate responses between this group and a group of countries with floating exchange rates.

A study by Sachs, et al (1984) analyzes the short-run impact of various types of fiscal measures as well as the dynamics of adjustment to long-run steady states. Their analysis and related simulations suggest that the effect of fiscal policy changes on the real exchange rate can vary widely and will depend closely on a number of structural features, including the degree of asset substitutability, the composition of government spending, and the initial size of the public debt and net external position.

A paper by Clarida, et al. (1999) paper presents some empirical results on the dynamic relationship between fiscal policy and the real exchange rate in the G3 countries since advent of floating exchange rates. They find a similarity across the G3 countries in their estimated dynamic responses to a fiscal shock. At first, and for several years thereafter, the real exchange rate appreciates in response to an expansionary fiscal shock. However, eventually, the process is reversed; the real exchange rate overshoots and actually depreciates relative to its initial prevailing before the fiscal shock.

Chen, et al. (2018) analyze the impact of government spending shocks on the real exchange rate in China over the period 1995Q1 - 2015Q2 using a structural VAR framework. To achieve identification, they derive robust restrictions on the sign of several impulse responses from an open economy general equilibrium model calibrated to China's economy. The results show that expansionary government consumption shocks and government investment shocks both lead to real exchange rate appreciation, which is in line with the prediction of the conventional Mundell-Fleming model.

Kollmannrt (2010), in his paper, paper presents a simple model with limited international risk sharing that can account for the empirical real exchange rate response. To him, when faced with a country-specific rise in government purchases, local households experience a negative wealth effect; they thus work harder and domestic output increases. Under balanced trade (financial autarky) this supply-side effect is so strong 
that the terms of trade worsen, and the real exchange rate depreciates. Hi also finds that, in a bonds-only economy, an increase in government purchases triggers real exchange rate depreciation, if the rise in government purchases is sufficiently persistent and/or labor supply is highly elastic.

Our study is different from other studies on this issue and thus contributes to the existing literature in many ways: (a) we investigate the impact of fiscal stimulus on the US dollar's exchange rate, which to our knowledge has not been done at least recently, (b) we develop and empirically test a model that combines Fisher's Quantity Theory equation, the Purchasing Power Parity equation, the national income identity, and the standard model for exchange rate determination and use a vector error correction model, and (c) we analyze both the short-run and the long-run impacts of US fiscal stimulus spending on the dollar's exchange rate.

\section{THE MODEL}

We build our model based on the Fisher's Quantity Theory equation as laid out below.

$\mathrm{MV}=\mathrm{PY}$

where, M, V, P, Y, and PY denote quantity of money supply in the economy, velocity of money, general price level in the economy, real and nominal output of the country respectively. The above identity can be expressed in terms of $\mathrm{P}$ as following:

$\mathrm{P}=\mathrm{MV} / \mathrm{Y}$

If $\mathrm{P}^{*}, \mathrm{M}^{*}, \mathrm{~V}^{*}$, and $\mathrm{Y}^{*}$ denote the general price level, quantity of money supply, velocity of money, and real output in a foreign country respectively, then identity (2) can be rewritten as,

$\mathrm{P}^{*}=\mathrm{M}^{*} \mathrm{~V}^{*} / \mathrm{Y}^{*}$

Using the Absolute Purchasing Power Parity theory, the exchange rate of domestic currency in terms of a foreign currency can be expressed as,

$\mathrm{E}=\mathrm{P} / \mathrm{P}^{*}$

Substituting identity (2) and (3) into (4) yields,

$E=\frac{M V / Y}{M^{*} V^{*} / P^{*}}$

If we assume $\mathrm{V}$ and $\mathrm{V}^{*}$ to be constant, as it is a custom in empirical studies, then, in a functional form the above identity can be written as,

$E=f\left(M, Y, M^{*}, Y^{*}\right)$

According to national income identity, a nation's output, Y, can be expressed as,

$\mathrm{Y}=\mathrm{C}+\mathrm{I}+\mathrm{G}+\mathrm{NX}$

Substituting identity (7) into function (6) yields,

$E=f\left(M,(C+I+G+N X), M^{*}, Y^{*}\right)$ 
Assuming that the mean effect of variables, C, I, and NX, is included in the intercept term, $\alpha_{0}$, and their random effect is included in the error term, $e_{t}$, then function (8), in its stochastic form, can be written as,

$E_{t}=\alpha_{0}+\alpha_{1} M_{t}+\alpha_{2} G_{t}+\alpha_{3} M_{t}^{*}+\alpha_{4} Y_{t}^{*}+e_{t}$

Here, $M_{t}, G_{t}, M_{t}^{*}$, and $Y_{t}^{*}$ are quantity of domestic money supply, amount of domestic government purchases, quantity of money supplied by the foreign country, and the foreign country's output respectively. We apply the model in (9) on US and China's data and estimate the above function for the US dollar.

\section{DATA}

We obtained the data on domestic money supply, M, and exchange rate of US dollar, E, from the Federal Reserve Bank of St. Louise (https://www.federalreserve.gov/datadownload/Download.aspx? rel $=H 10 \&$ series $=8 \mathrm{db} 0 \mathrm{be} 79 \mathrm{aaf} 2 \mathrm{~d} 1518083 \mathrm{cc} 4 \mathrm{ac} 8307 \mathrm{f} 8 \mathrm{c} \&$ filetype $=$ spreadsheetml $\&$ label=include $\&$ layout $=$ seriescolumn \&from $=01 / 01 / 1980 \&$ to $=12 / 31 / 2020$ ), US government purchases, $G$, from Bureau of Economic Analysis (https://apps.bea.gov/iTable/iTable.cfm?reqid=19\&step=2\#reqid=19\&step=2\&isuri= $1 \& 1921=$ survey), China's money supply, $\mathrm{M}^{*}$, from the Federal Reserve Bank of St. Louise (https://fred.stlouisfed.org/series/BOGNONBR), and China's GDP, Y*, from the World Bank (https://databank.worldbank.org/reports.aspx?source=World-Development-Indicators\#).

\section{METHODOLOGY AND EMPIRICAL FINDINGS}

For the model variables to be associated with each other by a long-run relationship, they all must be integrated of the same order. Therefore, we fist investigate if the model variables are stationary. To that end, we conduct the augmented Dickey-Fuller test and obtained the following results:

TABLE 2

DICKEY-FULLER TEST RESULTS

\begin{tabular}{|l|r|r|l|}
\hline \multicolumn{1}{|c|}{ Variable } & t-statistic & Critical Value at 10\% & \multicolumn{2}{c|}{ Stationary? } \\
\hline $\mathrm{E}$ & -1.16451 & -2.65519 & Non-stationary \\
\hline $\mathrm{d}(\mathrm{E}, 2)$ & -4.13758 & -2.66055 & Stationary \\
\hline $\mathrm{M}$ & 3.265471 & -2.65041 & Non-stationary \\
\hline $\mathrm{d}(\mathrm{M}, 2)$ & -4.70239 & -2.66659 & Stationary \\
\hline $\mathrm{G}$ & -0.61661 & -2.66659 & Non-stationary \\
\hline $\mathrm{d}(\mathrm{G}, 2)$ & -2.79837 & -2.66055 & Stationary \\
\hline $\mathrm{M}^{*}$ & 2.200875 & -2.66055 & Non-stationary \\
\hline $\mathrm{d}\left(\mathrm{M}^{*}, 2\right)$ & -6.32986 & -2.69044 & Stationary \\
\hline $\mathrm{Y}^{*}$ & 1.354807 & -2.65519 & Non-stationary \\
\hline $\mathrm{d}\left(\mathrm{Y}^{*}, 2\right)$ & -4.09136 & -2.66659 & Stationary \\
\hline
\end{tabular}

The results above show that all model variables are integrated of order 2 indicating a possibility of a long-run relationship among them. But before conducting a Johansen cointegration test to determine if any such relationship exists, we need to determine the appropriate lag length to be used in the cointegration test. So, we run a vector autoregressive model to determine the appropriate lag length and obtained the following results. 
TABLE 3

LAG LENGTH TEST FOR COINTEGRATION

\begin{tabular}{clrrrrr}
\hline Lag & LogL & \multicolumn{1}{c}{ LR } & \multicolumn{1}{c}{ FPE } & \multicolumn{1}{c}{ AIC } & \multicolumn{1}{c}{ SC } & \multicolumn{1}{c}{ HQ } \\
\hline 0 & -1459.734 & NA & $2.82 \mathrm{E}+57$ & 146.4734 & 146.7224 & 146.522 \\
1 & -1293.295 & $233.0156^{*}$ & $2.23 \mathrm{E}+51^{*}$ & $132.3295^{*}$ & $133.8231^{*}$ & $132.6210^{*}$ \\
\hline
\end{tabular}

As the above results show five out of six criteria indicate that the appropriate lag length is 1 . So, using a lag length of 1 we conducted the Johansen cointegration test that yielded the following results.

TABLE 4

UNRESTRICTED COINTEGRATION TEST

Unrestricted Co-integration Rank Test (Trace)

\begin{tabular}{|c|c|c|c|c|}
\hline \multicolumn{2}{|c|}{ Hypothesized } & \multirow{2}{*}{$\begin{array}{c}\text { Trace } \\
\text { Statistic }\end{array}$} & \multirow{2}{*}{$\begin{array}{c}0.05 \\
\text { Critical Value }\end{array}$} & \multirow[b]{2}{*}{ Prob.** } \\
\hline No. of CE(s) & Eigenvalue & & & \\
\hline At most $3 *$ & 0.68309 & 24.55715 & 15.49471 & 0.0017 \\
\hline At most 4 & 0.133544 & 2.723525 & 3.841465 & 0.0989 \\
\hline \multicolumn{5}{|c|}{ Unrestricted Cointegration Rank Test (Maximum Eigenvalue) } \\
\hline \multicolumn{2}{|c|}{ Hypothesized } & Max-Eigen & 0.05 & \\
\hline No. of CE(s) & Eigenvalue & Statistic & Critical Value & Prob.** \\
\hline At most $3 *$ & 0.68309 & 21.83363 & 14.2646 & 0.0027 \\
\hline At most 4 & 0.133544 & 2.723525 & 3.841465 & 0.0989 \\
\hline
\end{tabular}

Both tests indicate that there are four cointegrating vector among our model variables. Therefore, to determine any long-run and/or short-run relationship among our model variables we run a vector error correction model. Estimation of the model yielded the following results.

\section{Long-Run Equation:}

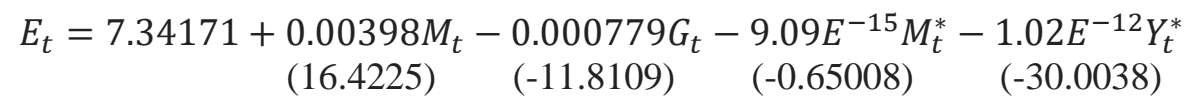

\section{Short-Run Equation:}

$$
\begin{aligned}
& \Delta \mathrm{E}_{\mathrm{t}}=-0.00261 \mathrm{ECT}_{\mathrm{t}-1}+0.118859 \Delta \mathrm{E}_{\mathrm{t}-1}+0.001333 \Delta \mathrm{M}_{\mathrm{t}-1}
\end{aligned}
$$

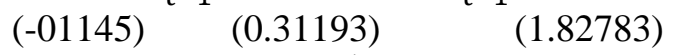

$$
\begin{aligned}
& -0.00094 \Delta \mathrm{G}_{\mathrm{t}-1}-6.96 \mathrm{E}^{-15} \Delta \mathrm{M}_{\mathrm{t}-1}^{*}-4.22 \mathrm{E}^{-13} \Delta \mathrm{Y}_{\mathrm{t}-1}^{*}+0.101747 \\
& \begin{array}{llll}
(-0.81883) & (-0.14713) & (-1.15566) & (0.38803)
\end{array}
\end{aligned}
$$

The figures in parentheses are corresponding t-values. In the long-run equation, the coefficient associated with the independent variables, $M$, is positive and statistically significant indicating that an increase in US money supply raises the dollar's exchange rate. It seems plausible, because increase in US money supply lowers the interest rate at home causing a capital outflow, raising the demand for foreign currencies and thereby raising the exchange rate. The coefficients associated with the variables, $\mathrm{Y}^{*}$ is negative and statistically significant, which indicates that an increase in China's output lowers the exchange rate. The explanation for this finding is, when China's output increases, its demand for goods and services increases increasing the demand for imports and, thereby, raising the demand for the US dollar and thereby 
it's exchange rate. The coefficient associated with the variable, $\mathrm{G}$, has turned out to the negative and statistically significant indicating that an increase in US government purchases lowers the exchange rate. The possible explanation of this finding could be that US government has been financing its increased spending through deficit budgeting and the deficits are being financed through internal and external borrowing, which increases domestic interest rate causing capital inflows and thereby lowering the exchange rate. In the short-run equation, all of the model variables, including $\mathrm{G}$, have turned out to be statistically insignificant indicating that any increase in US government purchases has no effect on the dollar's exchange rate in the short run.

\section{FIGURE 1 \\ IMPULSE RESPONSE FUNCTIONS}

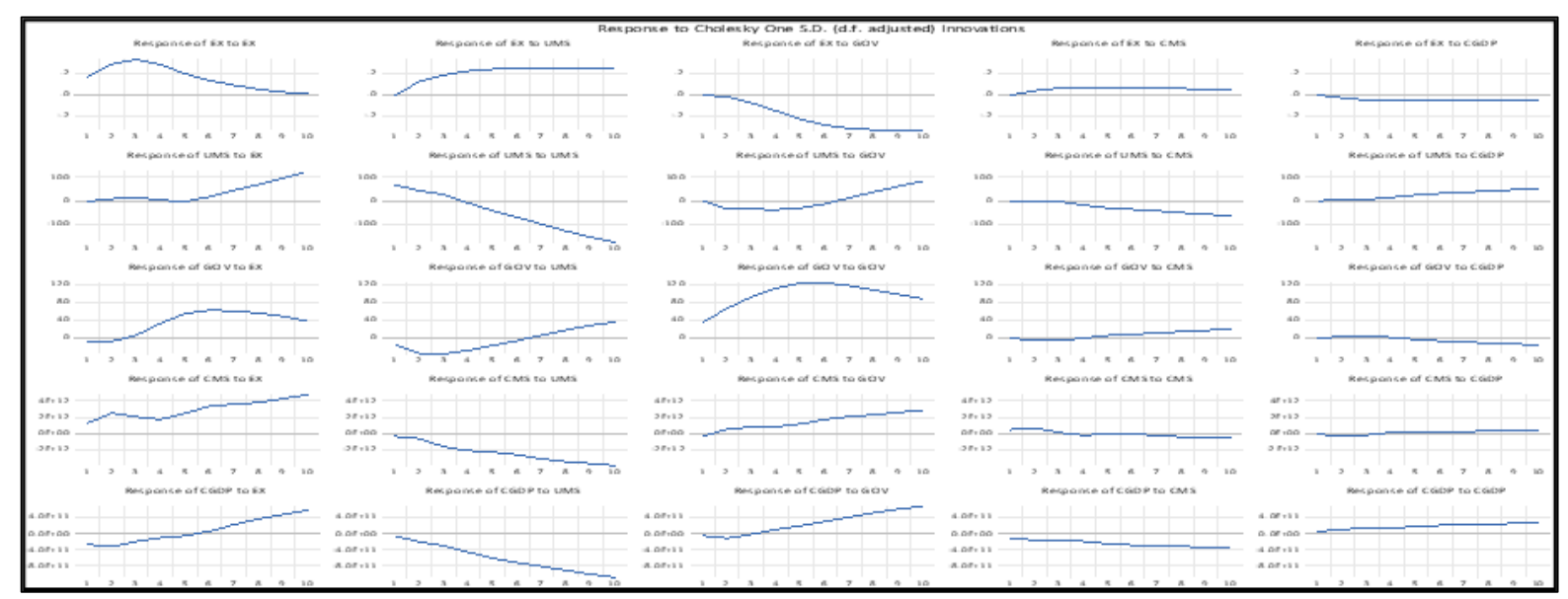

In order to test the robustness of our model, we measure the impulse responses of each of the model variable by giving one standard-deviation shock to each of our model variables. The graph in top middle panel of the above diagram shows the impulse response of exchange rate variable, EX, to one standarddeviation shock to US government spending variable, GOV. The impulse response function clearly indicates that any positive shock to US government spending has no effect until period-2 and then has a persistent negative effect on the dollar's exchange rate thereafter. This finding verifies that from our vector error correction model.

Also, the coefficient associated with the error-correction term, ECT, is negative but insignificant at 5\% significance level, which implies that any short-term fluctuation in the US dollar's exchange rate will not be adjusted toward its long-run value. However, it won't drift away from its long-run value either.

\section{SUMMARY AND CONCLUSION}

In last 90 years or so, presidents from both sides of the US political spectrum have used an expansionary fiscal policy in an attempt to take the U.S. economy out of recession or to stimulate the economy thought to be not growing fast enough.

The data on US government spending over the last 40 years shows a 6-fold rise from $\$ 589.6$ billion in 1980 to $\$ 3,830.2$ billion in 2020 . While a small increase in government spending on year-on-year basis is a regular phenomenon with the expansion in government activities due to increasing population, big spikes in US government spending, which we call fiscal stimulus, is largely targeted to boost the nation's GDP in an attempt to take the economy out of recession or to stimulate a sluggish economy. such a policy not only affects a nation's output, employment, and the rate of inflation, it also changes the pattern of income distribution, crowds out domestic investment, affects the exchange rate of domestic currency, and the 
pattern of international capital flows. In this study, we investigate whether the US stimulus policies (expansionary fiscal policies) have affected the value of or the exchange rate of US dollar.

We estimate a vector error correction model (VECM) on US and China's data ranging from 1980 to 2020. In the long run equation, the coefficient associated with the variable $G_{t}$ has been found to be negative and significant implying that US fiscal stimulus lowers the dollar's exchange rate. The possible explanation of this finding could be that US government has been financing its increased spending through deficit budgeting and the deficits are being financed through internal and external borrowing, which increases domestic interest rate causing capital inflows and thereby lowering the exchange rate. In the short-run equation, all of the model variables, including $\mathrm{G}$, have turned out to be statistically insignificant indicating that any increase in US fiscal stimulus will have no effect on the dollar's exchange rate in the short run. This finding has also been verified by impulse response functions. Thus, our findings imply that any fiscal stimulus actually improves the value of the dollar in the long run.

Our study has certain limitations as it does not breakdown the impact of various components of fiscal stimulus on the dollar's exchange rate. So, future studies can be focused on how each of the components of a fiscal stimulus, such as, a tax cut or stimulus checks, affects the dollar's exchange rage.

\section{REFERENCES}

Benetrix, A.S., \& Lane, P.R. (2013, September). Fiscal Shocks and the Real Exchange Rate. International Journal of Central Banking.

Born, B., Juessen, F., \& Mller G.J. (2013). Exchange Rate Regimes and Fiscal Multipliers. Journal of Economic Dynamics and Control, 37(2), 446-465.

Castro, F., \& Fernandez, L. (2013). The Effects of Fiscal Shocks on the Exchange Rate in Spain. The Economic and Social Review, 44(2).

Chen, Y., \& Liu, D. (2018, January). Government Spending Shocks and the Real Exchange Rate in China: Evidence from a Sign-restricted VAR Model. Economic Modelling, 68, 543-554.

Clarida, R., \& Prendergast, J. (1999, April). Fiscal Stance and the Real Exchange: Some Empirical Estimates. NBER, working paper no. 7077.

Cova, P., Pisani, M., \& Rebucci, A. (2011). Macroeconomic Effects of China's Fiscal Stimulus. Asia and China in the Global Economy, pp. 321-349.

Ilzetki, E., Mendoza, E.G., \& Vegh, C.A. (2010). How Big (Small?) are Fiscal Multipliers? NBER, working paper no. 16479.

Kollmann, R. (2010). Government Purchases and the Real Exchange Rate. Open Economies Review, 21, 49-64.

McKinnon, R., Lee, B., \& Wang, Y.D. (2010). The Global Credit Crisis and China's Exchange Rate. The Singapore Economic Review, 55(2), 253-272.

Monacelli, T., \& Perotti, R. (2010). Fiscal Policy, the Real Exchange Rate and Traded Goods. The Economic Journal, 120(544), 437-461.

Ravin, S.H., \& Spange, M. (2012). The Effects of Fiscal Policy in a Small Open Economy with a Fixed Exchange Rate: The Case of Denmark. ECONSTOR, Denmarks National Bank Working Papers No. 80.

Sachs, J., \& Wyplosz, C. (1984). Real Exchange Rate Effect of Fiscal Policy. NBER, working paper 1255.

Shibamoto, M., \& Shizume, M. (2014, July). Exchange Rate Adjustment, Monetary Policy and Fiscal Stimulus in Japan's Escape from the Great Depression. Explorations in Economic History, 53. 